\title{
CHEMICAL AND PHISICAL CHARACTERIZATION OF MEMORY BOARDS FROM OBSOLETE COMPUTERS THROUGH OPTICAL EMISSION SPECTROMETRY AND SCANNING ELECTRON MICROSCOPY
}

\author{
Marcos Paulo Kohler Caldas ${ }^{1,2}$ \\ Mariana Alves de Carvalho ${ }^{3}$ \\ Viviane Tavares de Moraes ${ }^{4}$ \\ Jorge Alberto Soares Tenório ${ }^{5}$ \\ Denise Crocce Romano Espinosa ${ }^{5}$
}

\begin{abstract}
The combination between the high volume of waste electrical and electronic equipment (WEEE) and the increased planned obsolescence makes it necessary thinking about alternative ways to dispose these wastes, such as recycling followed by metal recovery, without affecting the environment and human health. In order to do so, it is essential understanding the nature of the waste-constituent materials. Printed Circuit Boards (PCB) are important representatives of WEEE, since they are found in most electronic equipment such as computers. PCB heterogeneous composition comprises high metal contents - some of them are precious metals, which represent almost the entire intrinsic value of the board and that justifies applying recycling processes to recover them. The aim of the present study is to investigate the characterization of memory boards from obsolete computers for the subsequent recovery of its precious metals. It was possible to conclude that the memory board mass comprised $18.9 \%$ metals, $48.4 \%$ ceramics and $32.7 \%$ polymers. Cu was the most expressive metal, since it accounted for $13.83 \%$ of the board mass. Precious metals such as Ag and Au represented only $0.053 \%$ and $0.069 \%$ of the board mass, respectively; however, their high market value justifies their recovery.
\end{abstract}

Keywords: Recycling; Metal recovery; Characterization.

\section{INTRODUCTION}

The rampant consumption and the accelerated pace of technology's growth lead to a so-called planned obsolescence, which, along with the end of the operational life and malfunctions, turns electrical and electronic equipment into electronic scrap [1-4]. The increasing generation of this waste has evolved into an environmental issue. The main concern is associated with several chemical elements found in electronic and electrical scraps (many of them, such as mercury, lead and arsenic, are toxic to human health and environment), as well as with the improper disposal of these wastes $[5,6]$.

The situation gets even worse when scraps are disposed of in landfills, since the disposal of chemical elements that undergo leaching caused by fatty acids (from organic matter degradation) may lead to soil and groundwater contamination [7].
The disposal of metal wastes into the environment may lead to changes in soil density, toxicity, among other physicochemical properties, which result in ecological imbalance [8]. Several alternatives, such as the minimization of environmental impacts through the recycling and recovery of precious metals found in technology-related scraps, have been applied to avoid natural area and resource contaminations resulting from the disposal of these wastes $[9,10]$.

Recovering precious metals from printed circuit board (PCB) wastes became an interesting issue to companies, since precious metals and copper account for more than $95 \%$ of the total intrinsic value of the board and their concentration in the waste is up to 10 times higher than in ores [1 I-13]. It is the opportunity for companies to practice sustainable development by acquiring raw material (which is scarce in nature) derived from wastes $[14,15]$.

\footnotetext{
'Departamento de Engenharia Química, Escola Politécnica, Universidade de São Paulo - USP, São Paulo, SP, Brasil. E-mail: marcospaulo@usp.br ${ }^{2}$ Instituto Federal de Ciência, Educação e Tecnologia do Espírito Santo - IFES, Serra, ES, Brasil.

${ }^{3}$ Programa de Pós-graduação em Engenharia Química, Departamento de Engenharia Química, Escola Politécnica, Universidade de São Paulo - USP, São Paulo, SP, Brasil.

${ }^{4}$ Centro Universitário, Instituto Mauá de Tecnologia, São Caetano do Sul, SP, Brasil.

${ }^{5}$ Departamento de Engenharia Química, Escola Politécnica, Universidade de São Paulo - USP, São Paulo, SP, Brasil.
} 
The sustainable development is one of the motivations for recycling obsolete electrical and electronic equipment. The sustainability tripod (environmental preservation; WEEE reuse and remanufacturing; and inclusion of waste collectors to generate employment and income, as well as a way for companies to implement environmental marketing) is one of the challenges faced by waste electrical and electronic equipment (WEEE) management processes [16].

WEEE became the object of studies [17-19] aimed at minimizing risks to the environment and to human health. The concern lies on chemical elements found in printed circuit boards (PCBs) from electrical and electronic equipment (EEE), since a several amount of them are highly harmful to the environment and, consequently, to people's health; lead, mercury and cadmium stand out among these elements. In addition, WEEE have precious metals such as gold, silver and platinum, and these metals have boosted the recycling market [20].

The recovery of precious metals found in printed circuit boards is addressed is most studies about precious metal recycling $[3,5,6]$. The interest in recovering these metals dues to their higher added value in comparison to the value of other metals. As shown in Table I, the value of precious metals may reach more than $70 \%$ of the value spent on metals in the board's production process.

The added value of these metals suggests the need of recycling printed circuit boards. The recovery of these metals may be an alternative to obtain raw material for the synthesis of metallic nanoparticles, which are increasingly used in the industrial sector; thus, this topic has been addressed in a large number of studies about nanotechnology.

\section{MATERIALS AND METHODS}

Printed circuit memory boards - which here will be named as PCB-memory - from obsolete computers were assessed in the current study.

Table I. Composition and intrinsic value of metals found in printed circuit boards

\begin{tabular}{|c|c|c|c|}
\hline Metal & Mass $\%$ & Value $(\mathrm{f} / \mathbf{K g})$ & Value $\%$ \\
\hline Gold & 0.025 & 14200 & 65.4 \\
\hline Palladium & 0.01 & 6200 & 11.4 \\
\hline Copper & 16 & 3.3 & 9.7 \\
\hline Silver & 0.1 & 250 & 4.6 \\
\hline Tin & 3 & 8.1 & 4.5 \\
\hline Nickel & I & 13.2 & 2.4 \\
\hline Aluminum & 5 & 1.2 & I.I \\
\hline Lead & 2 & 1.3 & 0.5 \\
\hline Zinc & I & 1.2 & 0.2 \\
\hline Iron & 5 & 0.1 & 0.1 \\
\hline Others & - & - & 0,1 \\
\hline
\end{tabular}

Adapted from Park and Fray [2I].
The processes involved in this study were divided in SEM/EDS mapping region analysis, physical processing and characterization.

\section{I Microscope Analysis from PCB}

\section{I.I Binocular microscope analysis}

The binocular microscope analysis allowed investigating the exposure of the metallic surface of $\mathrm{PCB}$ components to observation. A cut was performed in the PCB in order to expose its composition; next, the cross section of the board was analyzed to identify the number of copper layers in it. The Zeiss magnifier, model stemi 2000-C, was used in the herein conducted analysis.

\subsubsection{SEM/EDS}

Memory boards subjected to SEM/EDS tests were cut at different points to allow visualizing the distribution of chemical elements, as well as the number of copper layers on it. These points were set in order to cover the largest number of components in the sample. The Phenom SEM device, model ProX, was adopted in the current study.

All the cut samples were embedded in epoxy resin.

\subsection{Physical Processing}

Approximately $5 \mathrm{~kg}$ of memory boards were used in the current study.

\subsection{Comminution}

A handheld guillotine was used to cut the PCBs in two parts in order to reduce their size and facilitate the milling process. Next, the PCBs were comminuted in two stages. The boards initially passed through a RONE FA2305 knife shredder ( $9 \mathrm{~mm}$ grid) and, then, through an Astecma hammer shredder model MDM I8/ 18 (2 $\mathrm{mm}$ grid) to reduce their size, increasing their surface area, and also to release materials in order to enable the metal recovery process [22]. After the PCB comminution stages were finished, the ground material was quartered, until obtaining $20 \mathrm{~g}$ fractions, to help better homogenizing the samples.

\subsection{Characterization}

\subsection{Digestion in aqua regia}

A quartered sample fraction was solubilized through direct contact with aqua regia solution at $\mathrm{HCl}-\mathrm{HNO}_{3}$ ratio $3: 1$, at solid-liquid ratio I:20 [2I] (I g of sample to $20 \mathrm{~mL}$ of aqua regia solution). Therefore, $5 \mathrm{~g}$ of sample were placed in direct contact with $100 \mathrm{~mL}$ of acid solution. The solubilization of metals in aqua regia was performed for 24 hours, at room temperature and pressure. 
Subsequently, the non-leached solid material was filtered from the leached liquor through simple filtration using quantitative filter paper $(0.75 \mu \mathrm{m}$ porosity $)$. The non-leached waste was washed in deionized water and oven-dried at $60{ }^{\circ} \mathrm{C}+/-5^{\circ} \mathrm{C}$, for 24 hours. An aliquot of $10 \mathrm{~mL}$ from the leached liquor was collected and subjected to chemical analysis through ICP-OES in order to determine the amount of metals in it.

\subsubsection{Inductively Coupled Plasma Optical Emission Spectroscopy (ICP-OES)}

Chemical analysis was performed through ICP-OES to determine metal concentrations in the leaching liquor.

\subsubsection{Loss on ignition}

The loss on ignition test was performed in a muffle oven at $800{ }^{\circ} \mathrm{C}$, for I hour. A fraction of the non-leached material (approximately $2 \mathrm{~g}$ ) was placed in a pre-weighed porcelain boat-shape crucible, which was heated in oven at $800{ }^{\circ} \mathrm{C}$, at heating rate $10^{\circ} \mathrm{C} /$ minute, for I hour. Next, the oven was turned off in order to cool down to room temperature.

The non-volatilized material in the crucible corresponded to the ceramic material found in the studied fraction. The difference between the initial and the calcined masses corresponded to the polymers in the PCB.

\section{RESULTS AND DISCUSSION}

\section{I PCB's Microscope Analysis}

\section{I.I Binocular microscope analysis}

A binocular microscope was used to assess the release of materials and the exposure of the metal surface of the PCB components, after the samples were comminuted.

Figure I shows the cross-sectional view of the memory board in a binocular microscope. It is possible

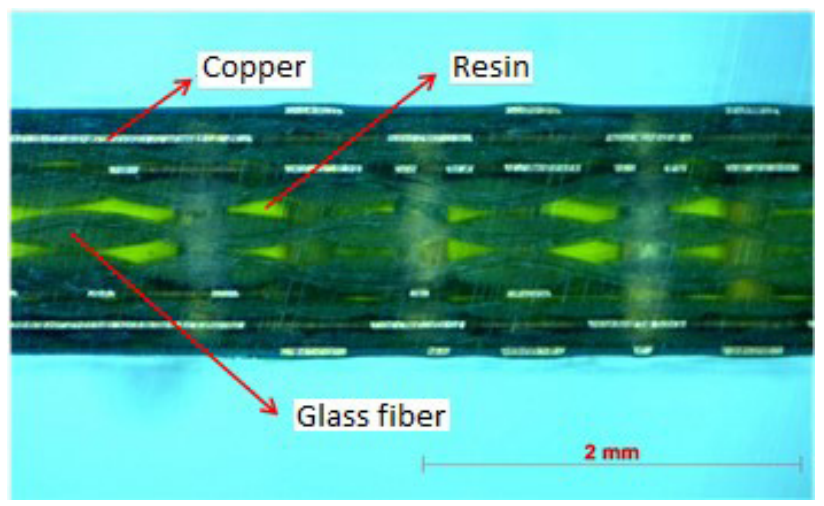

Figure I. Binocular microscope image showing the cross-section of the PCB-memory. seeing that the memory board was the multi-layer type and presented 6 copper layers interspersed by glass fiber and resin.

The copper layers appear as dotted (non-continuous) lines and represent the tracks of circuits that are not parallel to the cross section of the analyzed sample; they are very common in PCBs. The glass fibers may be identified as the corrugated material characterized by layers placed parallel and perpendicular to the cross-section surface. The parallels layers can be seen as sinusoidal waveforms, whereas the perpendicular layers intertwine with the parallel ones and form $90^{\circ}$ angles.

The binocular microscope analysis was not conclusive; therefore, it was necessary conducting the SEM/EDS analysis to confirm the elements visualized in the microscope.

\section{I.2 SEM/EDS}

The SEM/EDS analysis was applied to PCB-memory samples, which were previously embedded to help better visualizing the cross-section of the PCB base substrate; it allowed identifying the copper, glass fiber and resin layers.

Figure 2 shows the PCB-memory and the two sampling points subjected to SEM/EDS analysis. The sampling point and its respective position after resin embedding may be seen in the PCB-memory. Samples were identified as sampling $A$ and $B$.

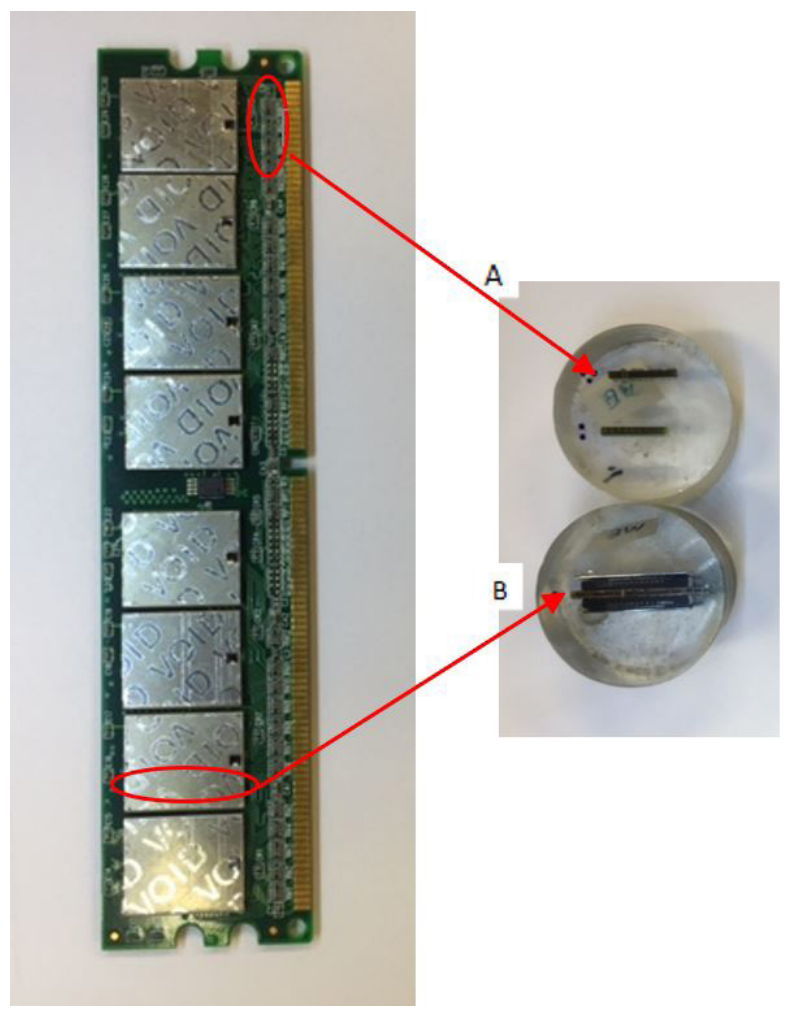

Figure 2. PCM-mem board with location of sampling points $A$ and $B$, and identification of resin-embedded samples. 


\section{I.2.I Sampling A}

The position of this sampling was set in a place containing some components welded to the memory board. The aim of the analysis applied to this point was to identify the weld used in the Surface Mount Device (SMD) components, as well as the arrangement and amount of copper layers, and the board substrate composition. Figure 3 presents the magnified image of sampling point $A$ in the PCB-memory and shows, in details, where the SEM/EDS analysis was conducted.

Figure 4 shows the mapping of the detailed area aimed at identifying the elements composing it.

Figure 4 presents the result of a SEM/EDS mapping. In the upper left corner of each mapping image its possible identify the color associated to one chemical element. Then the intense coloring indicates the presence of this chemical element. For example, in the image where is showed carbon (C), its possible to conclude that are glass fiber impregnated with resin (polymeric component with a carbon structure). In the case of the image that contains tin ( $\mathrm{Sn}$ ), its was possible identify a weld point in the PCB surface. The mapping did not illustrated the presence of lead $(\mathrm{Pb})$ in the same area of tin (this could be an indicative of an alloy $\mathrm{Sn} / \mathrm{Pb}$ usually applied in the weld), therefore it can be affirmed that the PCB studied were lead-free [23].

According to Figure 4, the glass fiber in the board was composed of silicon and calcium, whereas the resin was composed of aluminum and carbon. In addition, the tracks were made of copper and the weld was lead-free and basically composed of tin. There was a nickel layer between the weld and the copper tracks. Nickel was used as barrier in $\mathrm{Au} / \mathrm{Cu}$ metallization because $\mathrm{Ni}$-Sn compounds show very slow growth rates and because $\mathrm{Ni}$ presents low diffusion rate between $\mathrm{Au}$ and $\mathrm{Cu}$ [24].

Figure 5 shows the 4-point EDS spectra of the sample and indicates the composition of these points.

Figure 5 shows the EDS spectrum of sampling $A$ at points I, 2, 3 and 4. The EDS spectrum of point I shows that the weld in the memory board was composed of tin and silver and possibly lead-free, since no lead was found in it. The EDS spectrum of point 2 shows the copper layer in the memory board. The EDS spectrum of points 3 and 4 show that the glass fiber of the memory board substrate was composed of silicon and calcium, as well as that there was resin composed of aluminum and carbon between the glass fiber layers.

\section{I.2.2 Sampling B}

The position of this sampling was set in a place containing integrated circuits connected to the PCB-memory. The aim of the analysis applied to this point was to investigate the composition of the integrated circuits connected to the memory board and the substrate of these circuits; as well as to investigate whether the copper layers and the substrate remained similar to samplings A and B. Figure 6 presents the magnified image of sampling point $B$ in the PCB-memory and shows, in details, where the SEM/EDS analysis will be conducted.

The area detailed in Figure 6 was mapped to help identifying the chemical elements composing it. Figure 7 shows the mapping of the detailed area.

According to the mapping of sampling $B$ in the PCB-memory (Figure 7), the integrated circuit in the board had one copper layer and its substrate was composed of glass
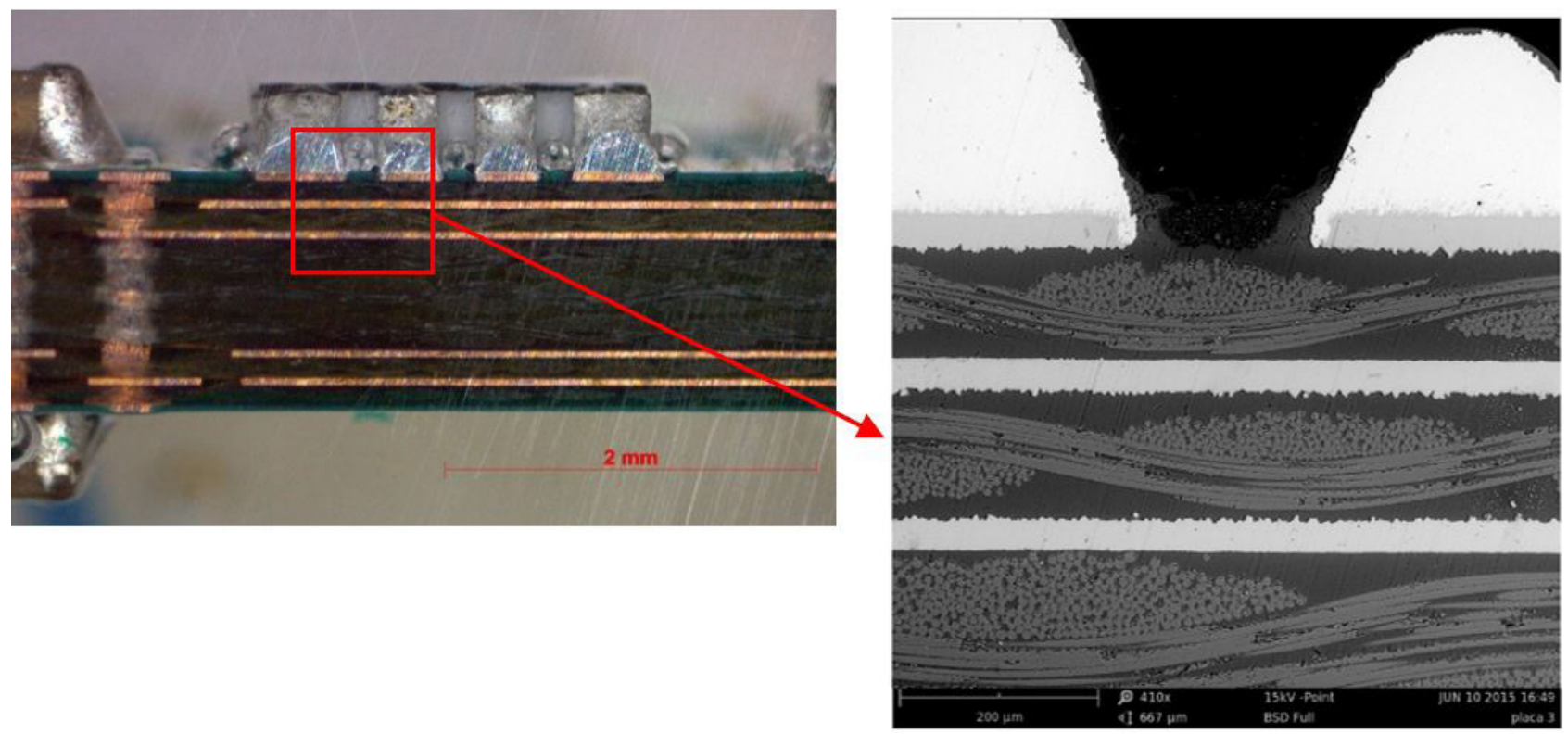

Figure 3. On the right, image showing retro-scattered electrons of sampling $A$ in the memory board. On the left, detail showing the region where the micrograph was analyzed. 


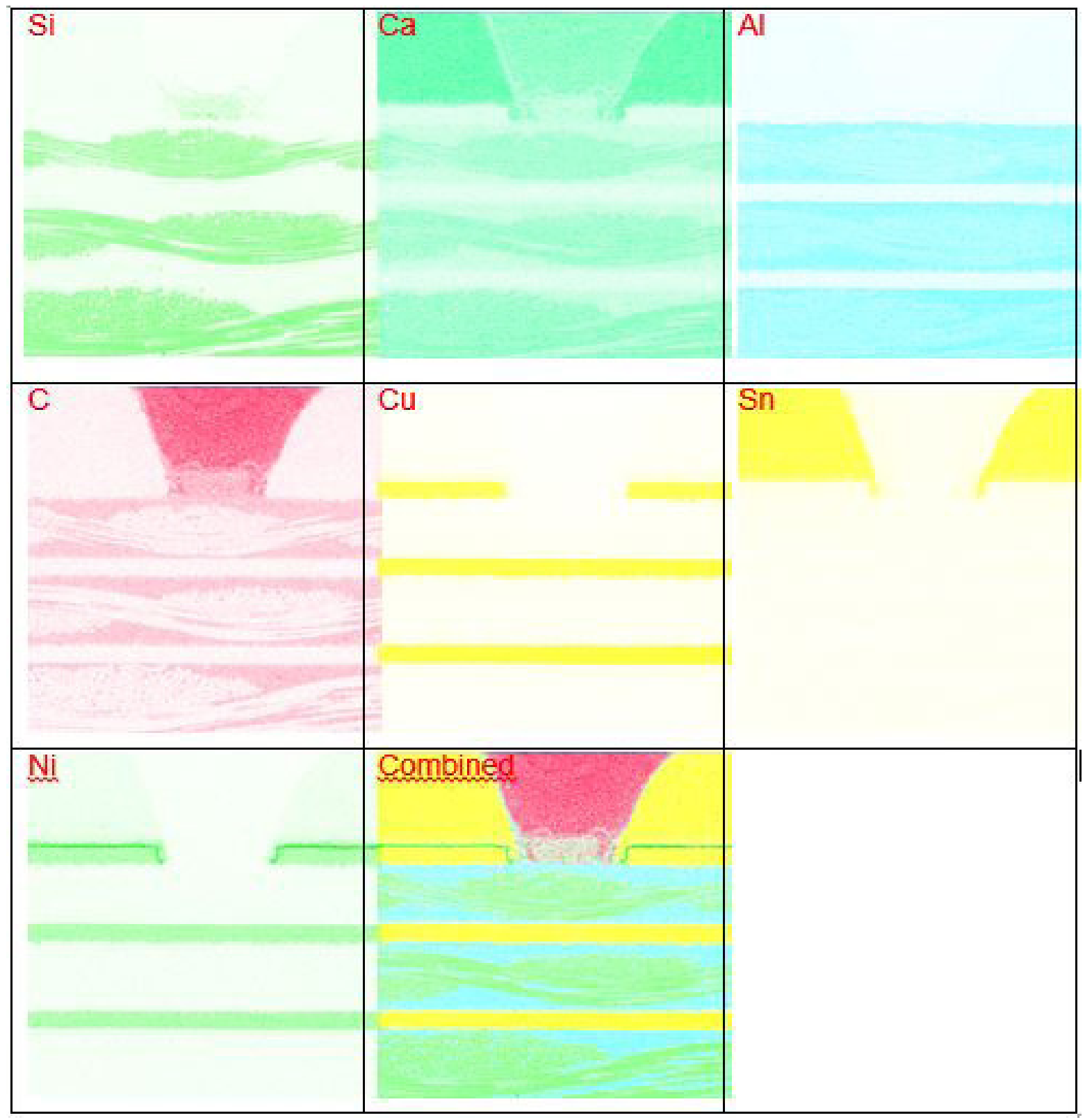

Figure 4. EDX images of the memory board, sampling A.

fiber and resin. As in the PCBs, the glass fiber was composed of silicon and calcium, whereas the resin between the glass fibers was basically composed of aluminum.

\subsection{Physical Processing}

Some components of the manually-dismantled memory board, such as aluminum heatsinks, processor holders and screws, were segregated, as shown in Figure 8.

The removal of these components was essential to help obtaining a loose part-free substrate in order to enable $\mathrm{PCBs}$ as similar as possible.

The PCBs were subjected to both comminution stages (milling in knife shredder followed by milling in hammer shredder), whose losses are shown in Table 2.
Table 2. Memory board mass balance after comminution

\begin{tabular}{ccc}
\hline Board & Milling & Loss (\%) \\
\hline PCB-memory & $9 \mathrm{~mm}$ & 0.17 \\
& $2 \mathrm{~mm}$ & 1.29 \\
& Total & 1.46 \\
\hline
\end{tabular}

The PCBs from comminuted motherboards were named PCB-memory.

The total mass loss in the PCB-memory was $1.46 \%$. Moraes [5] and Yamane [25] recorded 25\% and 30\% total mass loss, respectively, using equipment similar to that adopted in the current study. The herein recorded lower losses indicated that a more efficient comminution process was adopted in the current study, thus avoiding the loss of 
Chemical and phisical characterization of memory boards from obsolete computers through optical emission spectrometry and scanning electron microscopy

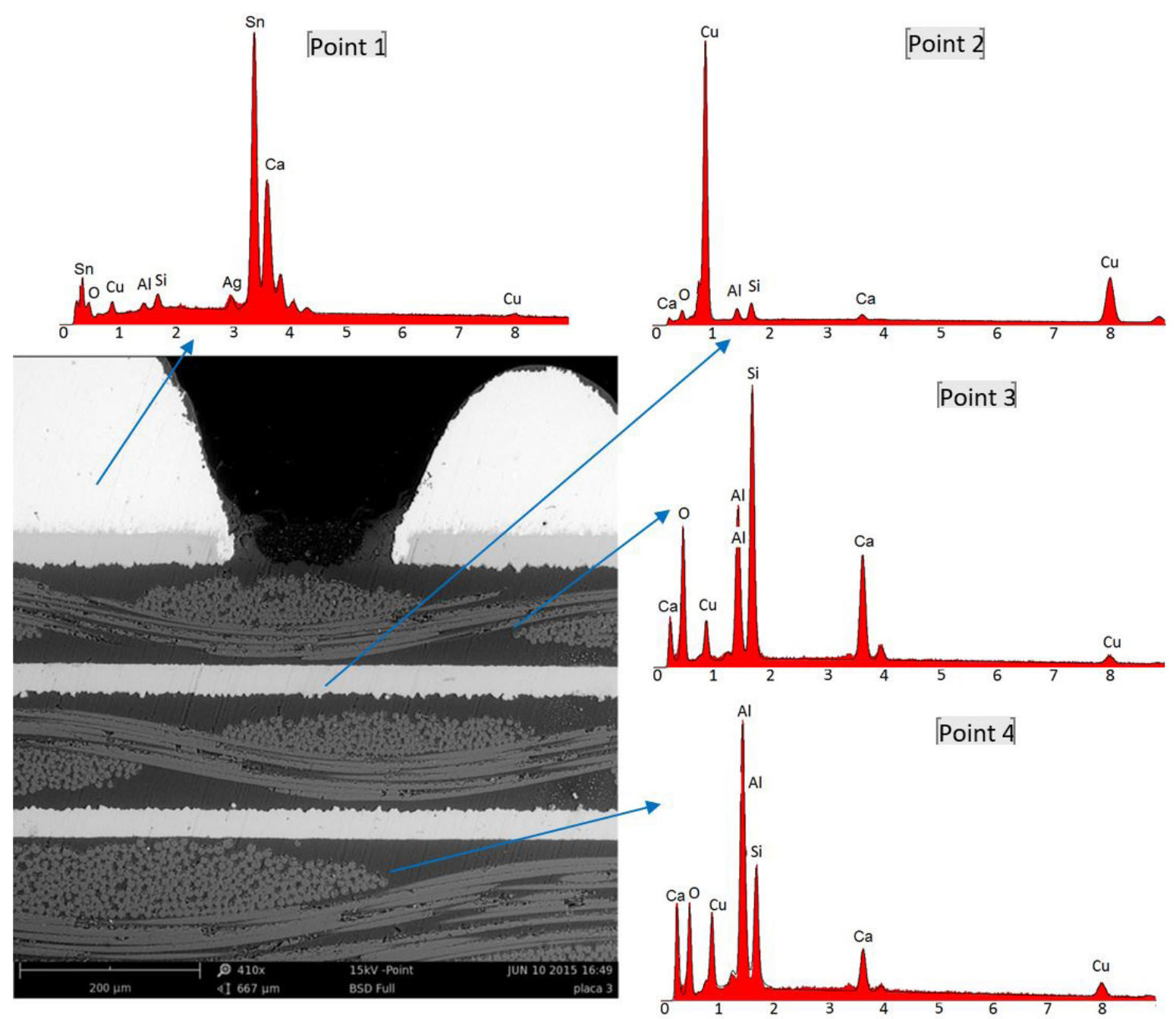

Figure 5. Image showing retro-scattered electrons of sampling A in the motherboard and the EDSs of points I (weld), 2 (copper track), 3 (glass fiber) and 4 (resin).
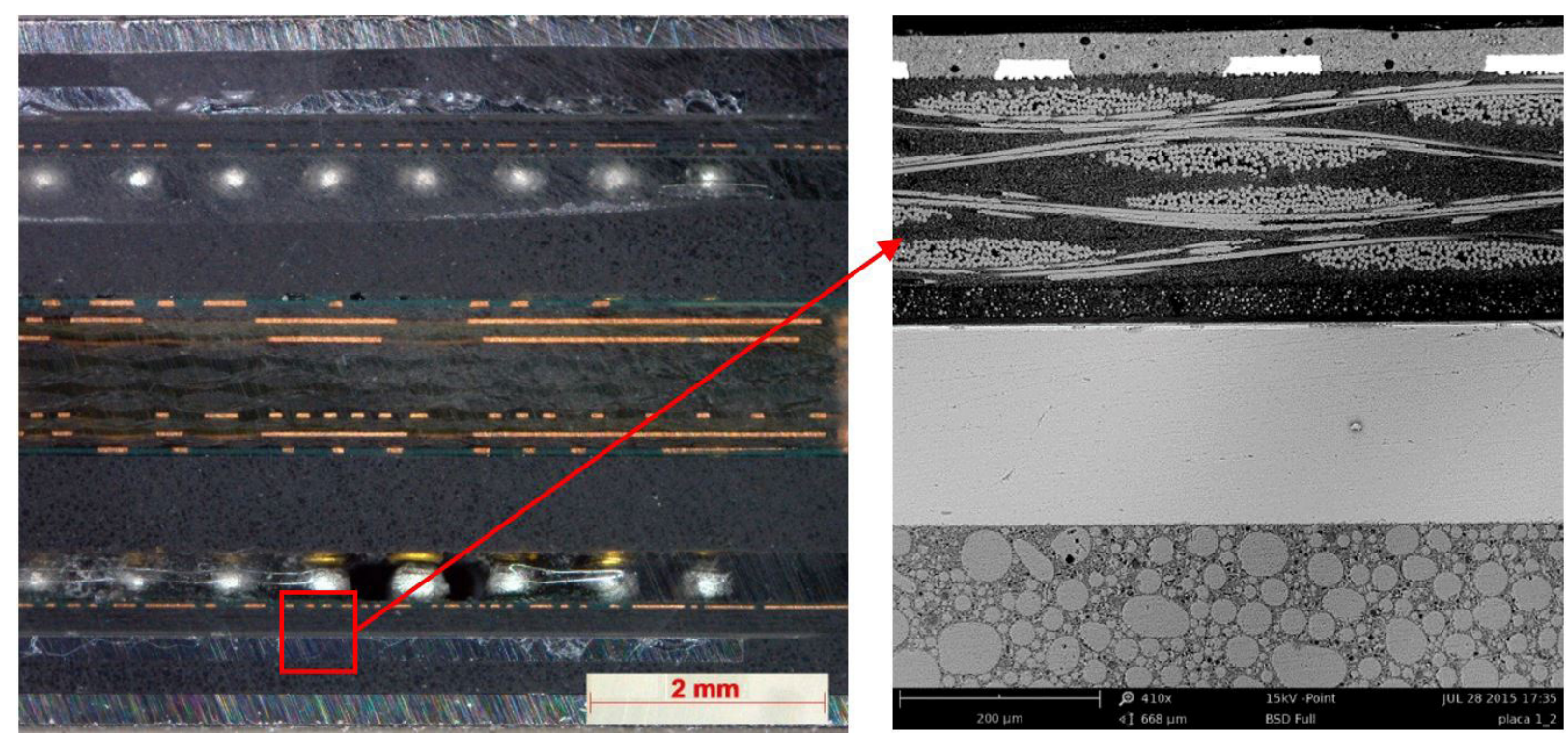

Figure 6. Image showing retro-scattered electrons of sampling B in the memory board. On the left, detail showing the region where the micrograph was analyzed. 


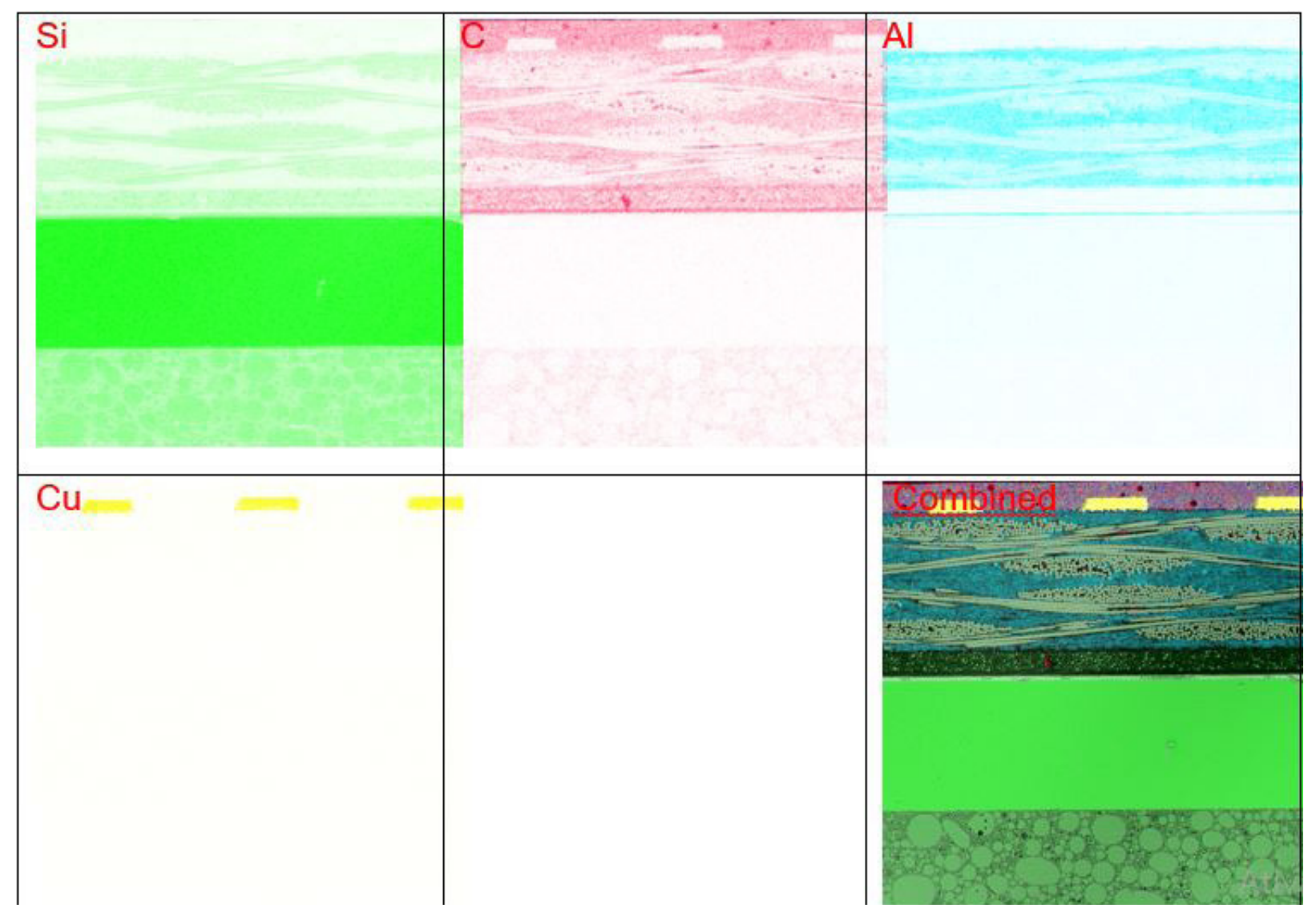

Figure 7. EDX images of the memory board, sampling B.
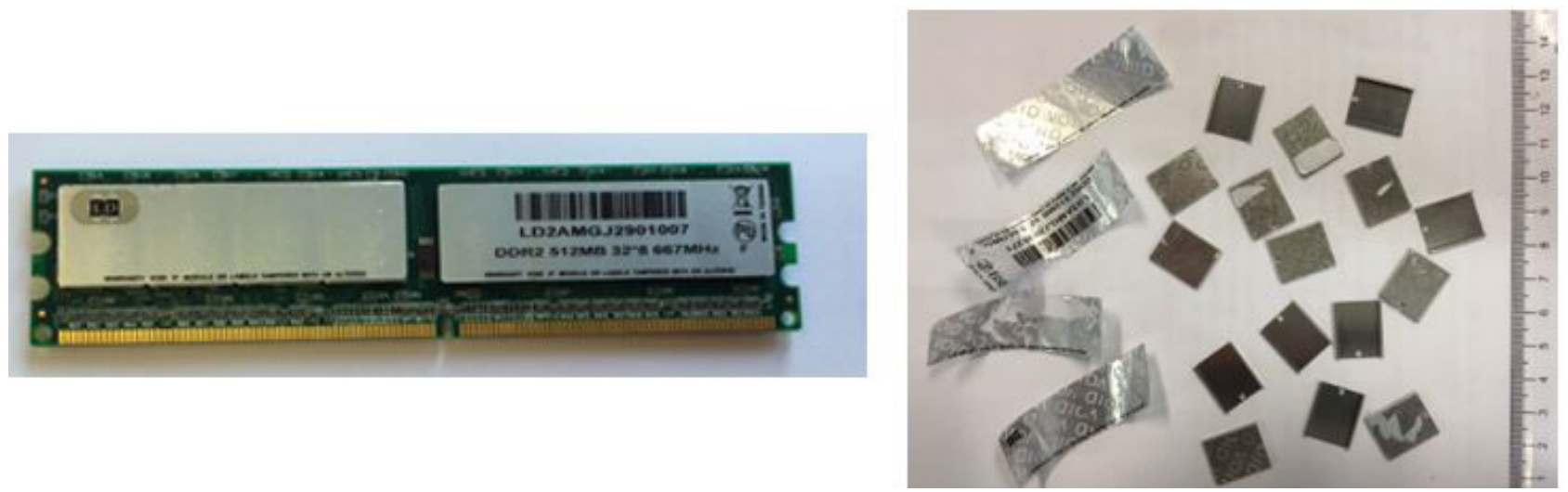

Figure 8. Memory board and components removed from it through manual dismantling.

fine elements. Lower mass losses during the comminution process allowed obtaining samples whose composition was closer to the actual composition of PCBs.

\subsection{Characterization}

\subsection{Digestion in aqua regia}

The aqua regia digestion test allowed determining the amount of metals composing the PCB by calculating the leached sample mass loss. Figure 9 shows the amount of metals in the printed circuit board as percentage of soluble materials. It is possible seeing that the board was composed of $19 \%$ metals (soluble material), as well as of $81 \%$ polymer and ceramic materials (insoluble material).

Others studies shows the materials composition from personal computers PCBs around 40 wt \% metals, $30 \mathrm{wt} . \%$ ceramics and $30 \mathrm{wt}$. $\%$ polymers [26-28]. A research from Yamane et al. [29] show that mobile phones PCBs are composed of $63 \mathrm{wt}$. \% metals; $24 \mathrm{wt}$. \% ceramics and I 3 wt. $\%$ polymers and PCB from personal computers have $45 \mathrm{wt} . \%$ metals; 27 wt. $\%$ polymers and ceramics 28 wt. $\%$ ceramics. 


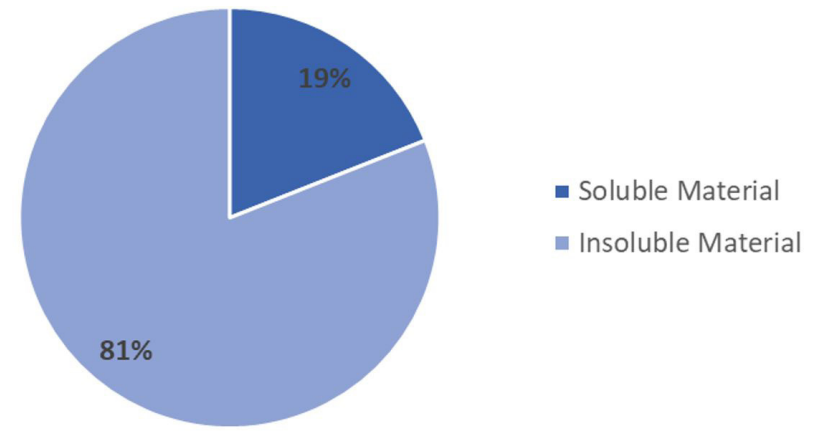

Figure 9. Percentage of soluble and insoluble materials composing the PCB.

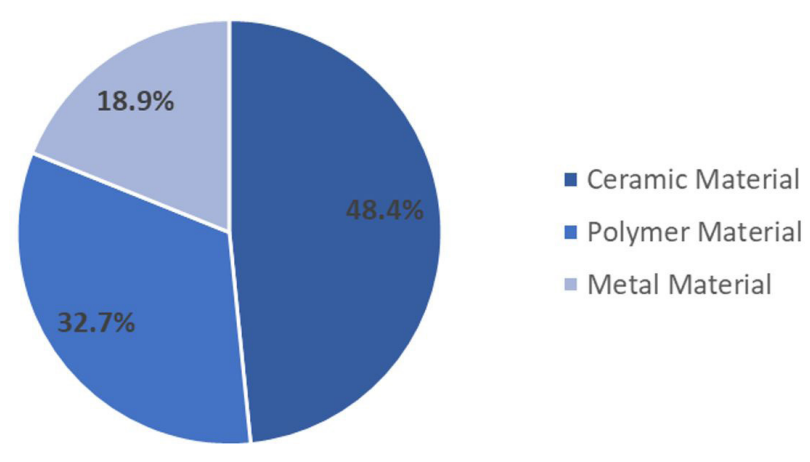

Figure 10. Composition of PCB materials.

\subsubsection{Inductively Coupled Plasma Optical Emission Spectrometry (ICP-OES)}

The $10 \mathrm{~mL}$ leached liquor aliquot was diluted to make it possible identify the metals in different concentrations. The metal concentrations in the PCB were calculated after the ICP-OES analysis, as shown in Table 3.

Copper recorded the highest concentration in the PCB, since it accounted for more than $13.83 \%$ of the board composition; it was followed by iron, which recorded more than $1.4 \%$ and by aluminum, with $1.43 \%$.

If one just takes into consideration metals, the copper mass amount was higher than the sum of all other metals, since copper was applied to the PCB layers due to its high conductivity capacity [I2].

Although noble metals accounted for less than $1 \%$ of the $\mathrm{PCB}$, the intrinsic value of these metals may reach $80 \%$ of the board value [ 13$]$.

The PCB-memory is a lead free composition because chemical analysis recorded the absence of lead and presence of tin in the weld, as specified by the ROHS directive [30].

\subsubsection{Loss on ignition}

The solid material that was not leached during the digestion in aqua regia was filtered and dried before its subjection to the loss on ignition test. The waste showed
Table 3. Results of the analysis applied to metals found in the leached liquor from aqua regia

\begin{tabular}{lcc}
\hline \multicolumn{1}{c}{ Metals } & PCB mass \% & Metal mass \% \\
\hline Silver & 0.053 & 0.28 \\
Aluminum & 1.43 & 7.56 \\
Gold & 0.069 & 0.36 \\
Copper & 13.83 & 73.10 \\
Iron & 1.47 & 7.77 \\
Nickel & 0.32 & 1.69 \\
Tin & 1.7 & 8.99 \\
Zinc & 0.043 & 0.23 \\
Total & 18.92 & 100.0 \\
\hline
\end{tabular}

$40.3 \%$ mass loss after it was removed from the oven and weighed. This value represents the mass percentage of the volatilized non-leached solid material, i.e., to the polymeric material. The amount of non-volatilized (ceramic) material in the boat-shape crucible was $59.7 \%$. It was possible seeing that $18.9 \%$ of the initial sample was solubilized during the digestion in aqua regia; this portion corresponded to the metal fraction of the initial sample. By applying the polymer and ceramic fraction percentages recorded in the loss on ignition test, it was possible stating that the herein studied PCB was composed of $32.7 \%$ polymer material and $48.4 \%$ ceramic material, as shown in Figure 10. These values partly corresponded to those recorded by Menetti [3I].

There was silver in the PCBs; this finding allowed estimating that silver nanoparticles may be recycled through milling, magnetic and electrostatic separation, solid-liquid and liquid-liquid extraction, crystallization and reduction processes.

\section{CONCLUSION}

The results recorded up to the present phase of the current study allowed concluding that the physical processing of PCB-mem was well succeeded, with low recorded material loss and the liberation of material for the chemical analysis.

The characterization also allowed the identification of the structure of PCB-memory: it is multi-layer type and present 6 cooper layers interspersed by glass fiber and resin. The glass fiber was composed of silicon and calcium and the resin was composed of aluminum and carbon. A nickel layer was identified between the weld and the cooper tracks, and it was used as a barrier in $\mathrm{Au} / \mathrm{Cu}$ metallization. Also, it was verified that $\mathrm{PCB}$-memory is lead free because chemical analysis recorded the absence of lead and presence of tin in the weld.

By chemical analysis it was possible to determine the percentage of each type of material and quantify the metals on PCB-memory, concluding that was composed of approximately $48 \%$ of ceramics, $33 \%$ of polymers and 
$19 \%$ of metals. Metallic fraction presents the following composition: $0.053 \% \mathrm{Ag}$; I.43\% Al; 0.069\% Au; 13.83\% $\mathrm{Cu}$; I.47\% Fe; $0.32 \% \mathrm{Ni}$; I.7\% Sn; and 0.043\% Zn. Silver has a high market value, which explain the fact that, even lower than other metals, the amount of silver shows the potential of recovering this metal.

\section{Acknowledgements}

To Federal Institute of Espírito Santo - Campus Serra, Department of Chemical Engineering - Polytechnic School - University of São Paulo. To the Federal Institute of Espírito Santo for the financial contribution destined to the translation of the article into English.

\section{REFERENCES}

I Fundação Joaquim Nabuco. III Seminário Internacional sobre Resíduos de Equipamentos Eletroeletrônicos, SIREE: cidades sustentáveis e experiências inovadoras na gestão de resíduos de equipamentos eletroeletrônicos. Recife: Porto Digital; 2013.

2 Schluep M, Hagelueken C, Kuehr R, Magalini F, Maurer C, Meskers C, et al. Recycling from e-waste to resources. Paris: UNEP; 2009.

3 Bertuol DA, Veit HM, Bernardes AM, Espinosa DCR, Tenório JAS. Resíduos urbanos tecnológicos: desafios e tendências. Revista Metalurgia e Metais. 2005;61:167-170.

4 Yamane LH. Lixiviação bacteriana de sucata eletrônica: influência dos parâmetros de processo. São Paulo: Associação Brasileira de Metalurgia e Materiais; 2013. p. 50-56.

5 Moraes, VT. Recuperação de Metais a Partir do Processamento Mecânico e Hidrometalúrgico de Placas de Circuito Impressos de Celulares Obsoletos. Escola Politécnica da Universidade de São Paulo (EPUSP), p. I19, 201 I.

6 Babu BR, Parande AK, Basha CA. Electrical and electronic waste: a global environmental problem. Waste Management \& Research. 2007;25(4):307-318.

7 Luppi TVS. Recuperação de prata a partir de radiografias. In: Anais do $3^{\circ}$ Seminário de Tecnologia e Pesquisas Ambientais. SENAI; 2008.

8 Furtado JGC. Estudo de impactos ambientais causados por metais pesados em água do mar na baía de São Marcos: correlações e níveis background. João Pessoa: Universidade Federal da Paraíba; 2007.

9 Domingues TCG. Teor de metais pesados em solo contaminado com resíduo de sucata metálica, em função de sua acidificação [dissertação]. Campinas: Instituto Agronômico; 2009.

10 Gurung M, Adhikari BB, Kawakita H, Ohto K, Inoue K, Alam S. Recovery of gold and silver from spent mobile phones by means of acidothiourea leaching followed by adsorption using biosorbent prepared from persimmon tannin. Hydrometallurgy. 2013;133:84-93. http://dx.doi.org/10.1016/j.hydromet.2012.12.003.

I Guo J, Rao Q, Xu Z. Application of glass-nonmetals of waste printed circuit boards to produce phenolic moulding compound. Journal of Hazardous Materials. 2008; I53(I-2):728-734. http://dx.doi.org/10.1016/j. jhazmat.2007.09.029. PMid: 17949900.

$12 \mathrm{He} \mathrm{W}$, Li G, Ma X, Wang H, Huang J, Xu M, et al. WEEE recovery strategies and the WEEE treatment status in China. Journal of Hazardous Materials. 2006; I36(3):502-5 I2. http://dx.doi.org/I0.1016/j.jhazmat.2006.04.060. PMid: 16820262.

I 3 Li J, Lu H, Guo J, Xu Z, Zhou Y. Recycle technology for recovering resources and products from waste printed circuit boards. Environmental Science \& Technology. 2007;4I(6): 1995-2000. http://dx.doi.org//0.102 I/es06/8245. PMid: 17410796.

14 Naseri Joda N, Rashchi F. Recovery of ultra fine grained silver and copper from PC board scraps. Separation and Purification Technology. 2012;92:36-42. http://dx.doi.org/I0.1016/j.seppur.20I2.03.022.

15 Petter PMH, Veit HM, Bernardes AM. Evaluation of gold and silver leaching from printed circuit board of cellphones. Waste Management. 2014;34(2):475-482. http://dx.doi.org/I0.1016/j.wasman.2013.10.032. PMid:24332399.

16 Ewald MR. Equipamentos Eletroeletrônicos - Requisitos para atividade de manufatura reversa. <http://www.abnt. org.br/imagens/eventos_comunicacao/Lancamento_ABN TNBR_16156.pdf>. Acesso em: 25 jul. 2015

17 Das A, Vidyadhar A, Mehrotra SP. A novel flowsheet for the recovery of metal values from waste printed circuit boards. Resources, Conservation and Recycling. 2009;53(8):464-469. http://dx.doi.org//0.1016/j. resconrec.2009.03.008. 
18 Rochat D, Hagelüken C, Keller M, Widmer R. Optimal recycling for Printed Wiring Boards (PWBs) in India. In: Proceedings of the R'07 World Congress, Recovery of Materials and Energy for Resource Efficiency; 2007; Davos, Switzerland. Davos; 2007.

19 Abrantes R. Reciclagem de placas de circuito impresso: optimização da operação de processamento físico. Lisboa: Instituto Superior Técnico, Universidade Técnica de Lisboa; 2009. p. 97.

20 Oguchi M, Sakanakura H, Terazono A. Toxic metals in WEEE: characterization and substance flow analysis in waste treatment processes. The Science of the Total Environment. 2013;463-464: I I24- I I32. http://dx.doi.org/ I0. I0 I6/j. scitotenv.2012.07.078. PMid:229215I0.

2I Park YJ, Fray DJ. Recovery of high purity precious metals from printed circuit boards. Journal of Hazardous Materials. 2009; I64(2-3): I I52-I I58. http://dx.doi.org/I0. I0I6/j.jhazmat.2008.09.043. PMid: I8980802.

22 Yamane LH, Moraes VT, Espinosa DCR, Tenório JAS. Recycling of WEEE: characterization of spent printed circuit boards from mobile phones and computers. Waste Management. 20I I;3I(I2):2553-2558. http://dx.doi. org/I0.1016/j.wasman.2011.07.006. PMid:21820883.

23 Tu PL, Chan YC, Hung KC, Lai JKL. Growth kinetics of intermetallic compounds in chip scale package solder joint. Scripta Materialia. 200I;44(2):317-323. http://dx.doi.org/10.1016/SI359-6462(00)00590-X.

24 Alam MO, Chan YC, Hung KC. Reliability study of the electroless Ni-P layer against solder alloy. Microelectronics and Reliability. 2002;42(7): I065-1073. http://dx.doi.org/I0.1016/S0026-27I4(02)00068-9.

25 Yamane LH. Recuperação de metais de placas de circuito impresso de computadores obsoletos através de processo biohidrometalúrgico [tese]. São Paulo: Universidade de São Paulo; 20I2. http://dx.doi.org/I0.I I606/T.3.20I2. tde-07062013-154359.

26 Işıldar A, van Hullebusch ED, Lenz M, Du Laing G, Marra A, Cesaro A, et al. Biotechnological strategies for the recovery of valuable and critical raw materials from waste electrical and electronic equipment (WEEE): a review. Journal of Hazardous Materials. 2019;362:467-48I. http://dx.doi.org/10.1016/j.jhazmat.2018.08.050. PMid:30268020.

27 Mesquita RA, Silva RAF, Majuste D. Chemical mapping and analysis of electronic components from waste PCB with focus on metal recovery. Process Safety and Environmental Protection. 2018; 120:107-1 17. http://dx.doi. org//0.1016/j.psep.2018.09.002.

28 Veit HM, Bernardes AM, Ferreira JZ, Tenório JA, Malfatti CF. Recovery of copper from printed circuit boards scraps by mechanical processing and electrometallurgy. Journal of Hazardous Materials. 2006; I37(3): I 704- I 709. http:// dx.doi.org/I0.1016/j.jhazmat.2006.05.010. PMid:16757II6.

29 Yamane LH, Moraes VT, Espinosa DCR, Tenório JAS. Recycling of WEEE: characterization of spent printed circuit boards from mobile phones and computers. Waste Management. 20I I;3I(I2):2553. PMid:2 I820883.

30 European Union. Directive 2002/95/EC of the European Parliament and of the Council on the Restriction of the Use of Certain Hazardous Substances in Electrical and Electronic Equipment (RoHS). Official Journal of the European Union. $2003 \mathrm{Fev} 13$.

3I Menett RP, Chaves AP, Tenório JAS. Obtenção de concentrados metálicos não ferrosos a partir de sucata eletrônica. Anais do 5 I Congresso Anual da Associação Brasileira de Metalurgia e Materiais, vol. 4. Porto Alegre, RS I996. p. 95.

Received: 31 Mar. 2018

Accepted: 8 Nov. 2018 